\title{
$1: 32426801-32468317$
}

National Cancer Institute

\section{Source}

National Cancer Institute. 1:32426801-32468317. NCI Thesaurus. Code C42456.

Physical location of HDAC1_Gene 